

\title{
Application of geophysical measurements for assessing the role of fissures in water infiltration within a clay landslide (Trièves area, French Alps)
}

Grégory Bièvre, Denis Jongmans, Thierry Winiarski, Vilma Zumbo

\section{To cite this version:}

Grégory Bièvre, Denis Jongmans, Thierry Winiarski, Vilma Zumbo. Application of geophysical measurements for assessing the role of fissures in water infiltration within a clay landslide (Trièves area, French Alps). Hydrological Processes, 2012, 15 p. 10.1002/hyp.7986 . insu-00522885

\section{HAL Id: insu-00522885}

\section{https://hal-insu.archives-ouvertes.fr/insu-00522885}

Submitted on 4 Oct 2010

HAL is a multi-disciplinary open access archive for the deposit and dissemination of scientific research documents, whether they are published or not. The documents may come from teaching and research institutions in France or abroad, or from public or private research centers.
L'archive ouverte pluridisciplinaire HAL, est destinée au dépôt et à la diffusion de documents scientifiques de niveau recherche, publiés ou non, émanant des établissements d'enseignement et de recherche français ou étrangers, des laboratoires publics ou privés. 


\title{
Application of geophysical measurements for assessing the role of fissures in water infiltration within a clay landslide (Trièves area, French Alps)
}

\author{
Grégory Bièvre $^{a, b, 1}$, Denis Jongmans ${ }^{a}$, Thierry Winiarski ${ }^{c}$ and Vilma Zumbo ${ }^{b, d}$
}

a Laboratoire de Géophysique Interne et Tectonophysique, CNRS, Université Joseph Fourier, BP 53, 38041 Grenoble Cedex 9, France.

b Centre d'Études Techniques de l'Équipement de Lyon, Laboratoire Régional d'Autun, BP 141, 71404 Autun cedex, France.

c Laboratoire des Sciences de l'Environnement, École Nationale des Travaux Publics de l'État - Université de Lyon, 3 rue Maurice Audin, 69518 Vaulx-en-Velin cedex, France.

d Inexia Ingénierie, 1 place aux étoiles, 93212 Saint-Denis-La-Plaine cedex, France.

\begin{abstract}
Rainfall and its consequences are usually considered as the major factor triggering slope instabilities within clay deposits. The link between rainfall, water infiltration and landslide activity may be complex and comprehensive sets of data are still necessary to understand how water infiltrates in cohesive material. On unstable slopes made of fine-grained sediments, gravitational deformation generates superficial shear ruptures and tension fissures whose continuous opening could be amplified by shrinkage during dry periods. This fissure network at the surface can be very dense and strongly controls the water infiltration process. However, it remains difficult to assess the fissure evolution at depth and its eventual relationship with shallow slip surfaces. This work presents the results of a geophysical study which aimed to characterize the fissures that are observed along the unstable clay slopes of the Trièves area (French Alps). The site was first investigated combining geomorphological analysis, drilling, borehole logging, geotechnical tests and geophysical experiments. This investigation evidenced the presence of at least three rupture surfaces (at $5 \mathrm{~m}, 10$ to $15 \mathrm{~m}$ and $42 \mathrm{~m}$ ) with a water flow at the second one. In a second step, permanent instruments were installed (piezometers and soil water content (SWC) probes). Results indicate high water infiltration velocities, down to the water table located at $2.5 \mathrm{~m}$ depth, that are likely to be linked with sub-vertical preferential paths, such as fissures. Geophysical parameters (electrical resistivity, S-wave velocities, Rayleigh waves attenuation) were monitored. Geophysical results suggest that fissures are permanently open, that they serve as preferential infiltration paths, and that they can reach, at least, a depth of $2 \mathrm{~m}$. The methods employed in this research put forward that the system of imbricated fissures drains water from the surface down to the shallow slip surfaces at $5 \mathrm{~m}$ and 10-5 $\mathrm{m}$. This work highlights the role of fissures network in water infiltration in the numerous clay landslides of the Trièves area.
\end{abstract}

keywords: clays, fissures, landslide, water infiltration, geophysics

\footnotetext{
${ }^{1}$ corresponding author: gbievre@ujf-grenoble.fr
} 


\section{Introduction}

Many regions of the world are exposed to landslides in clay deposits, which pose major problems for land management and population safety (Giraud et al., 1991; Panizza et al., 1996; Guzetti, 2000; Picarelli et al., 2005). Rainfall and its consequences are usually considered as the major factor triggering slope instabilities (Iverson, 2000; Picarelli et al., 2004; Meisina, 2006; Tofani et al., 2006). Numerous observations and measurements show such a correlation between rainfalls and landslide activity (Moser and Hohensinn, 1983; Wilson and Wieczorek, 1995; Terlien, 1998; Aleotti, 2004; Chen et al., 2005), leading authors to propose global rainfall intensity-duration thresholds for the occurrence of shallow landslides and debris flows (Guzetti, 2000; Aleotti, 2004). Indeed, short duration and intense rainfalls often trigger superficial landslides (Corominas, 2001). On the contrary, slow moving deep-seated landslides in clay seem to be more sensitive to long duration and moderate intensity precipitation, and show more complex mechanical and fluid interactions (Comegna et al., 2007; Van Asch et al., 2007, 2009). In exceptional conditions, they can evolve into sudden catastrophic failures and flows, resulting from generation of excess pore pressure along slip surfaces (Picarelli et al., 2004; Van Asch et al., 2006). The link between rainfall, water infiltration and landslide activity may be complex (Van Asch et al., 2007) and comprehensive sets of data are still necessary to understand how water infiltrates in cohesive materials (Malet et al., 2003; Lindenmaier et al., 2005; Van Asch et al., 2009). Observations and theoretical works on shrinkage fissures in drying soils (Morris et al., 1992) indicated that they could extend to a depth of a few meters and greatly affect infiltration in the soil. A study of weathered clayey soils responsible of shallow landslides (Meisina, 2006) showed that desiccation fissures in drought periods could reach a depth of 1.4-1.9 m, providing a preferential path for water.

On unstable slopes, gravitational deformation generates superficial shear ruptures and tension fissures, which are often near parallel to contour lines and whose continuous opening could be amplified by shrinkage during dry periods. For active landslides, the fissure network at the surface can be very dense (several fissures per m) and strongly controls the water infiltration process (Malet et al., 2003; Krzeminska et al., 2009). Because of the difficulty to assess the fissure evolution at depth, in-situ precipitation simulations associated to hydrogeological and/or hydrogeophysical monitoring were performed to analyse the water infiltration in fine-grained soils (Gvirtzman et al., 2008; Krzeminska et al., 2009; Tu et al., 2009). In particular, Krzeminska et al. (2009) conducted a two-day small-scale infiltration on an active marly mudslide characterized by the presence of a wide-open fissure system $(5 \mathrm{~cm})$ at the surface. This experiment was monitored with electrical resistivity tomography measurements carried out every two hours. During all the artificial rainfall experiment, a front of low resistivity propagated laterally in the superficial $(30 \mathrm{~cm})$ soil layer, resulting from the increase of water content. During the second day, the development of a narrow near-vertical low resistivity zone (down to 0.5-0.6 m) was observed, that was interpreted as a downward water infiltration. These results highlighted the hydrological processes of a preferential flow inside the mass.

The aim of this paper is to apply different geophysical techniques in an attempt to assess the role of fissures, that are observed along the unstable clay slopes of the Trièves area, as preferential paths for water infiltration. The chosen site is a small-size (100 $\mathrm{m}$ by $50 \mathrm{~m})$ active landslide nested in the large deep-seated landslide of Avignonet which was geo- 
physically studied by Jongmans et al. (2009). First, the site was thoroughly investigated combining geomorphological analysis, drilling, borehole logging, geotechnical tests and geophysical experiments (seismic and electrical methods). This new investigation campaign evidenced the presence of at least three rupture surfaces at about $5 \mathrm{~m}, 10$ to $15 \mathrm{~m}$ and $42 \mathrm{~m}$. In a second step, permanent instruments were installed, including piezometers and soil water content (SWC) probes. GPS stations were installed to measure ground displacements. Geophysical parameters (electrical resistivity, S-wave velocity, Rayleigh waves attenuation) were monitored and results allowed an hydrogeological scheme to be proposed for the site.

\section{Geological and hydrogeological contexts}

The Trièves depression is located in the western Alps, $40 \mathrm{~km}$ south of the City of Grenoble (Figure 1). This flat area is bounded by the carbonate Vercors range to the West, the carbonate Dévoluy massif to the South and the southern end of the crystalline Belledonne range to the East. During the last Quaternary glaciation (Würm), the Isère glacier moving in a southward direction dammed the rivers flowing from the South, creating a lake during several thousands of years (Monjuvent, 1973). Laminated clays resulting from the erosion of the surrounding ranges progressively filled the lake. They are usually made of a succession of thin laminae ( $\mathrm{mm}$ to $\mathrm{cm}$ size) of light silt and dark clay, although some unlaminated clay layers with blocks can also be found (Monjuvent, 1973). These laminated clays, which are locally interbedded with coarser alluvial sediments deposited during the interglacial Riss-Würm period, overly the folded carbonate bedrock. Total clay thickness varies between 0 to a maximum of $250 \mathrm{~m}$ (Antoine et al., 1981). In the studied area (Figure 1), laminated clays were partly covered by a few $\mathrm{m}$ to $10 \mathrm{~m}$ thick morainic deposits. After the glacier melting (14,000 years BP, after Brocard et al., 2003), the rivers cut deeply into the geological formations, generating numerous landslides in the clay deposits (Giraud et al., 1991).

The activity of these landslides is usually seasonal with an increase in displacement rate after snowmelt and heavy rain falls (Giraud et al., 1991; Van Asch et al., 1996). In most cases, landsliding process in the clay is slow and complex, with several slip surfaces between a few $\mathrm{m}$ to a maximum of $40 \mathrm{~m}$ depth (Giraud et al., 1991; Van Asch et al., 2009). Laminated clays on the slopes are usually overlaid with a more permeable colluvial cover varying in thickness from 1 to $4 \mathrm{~m}$ (Van Asch et al., 1996). A hydrogeological conceptual model was developed for explaining the triggering effect of the snowmelt and precipitation on the clay slopes of the Tièves area (Figure 2, modified from Nieuwenhuis, 1991; Vuillermet et al., 1994; Van Asch et al., 1996). Water first infiltrates in the permeable colluvial cover and generates a perched ground water table in this layer, which directly responds to rainfalls. This water mass feeds the open fissures that can be caused by desiccation during dry periods and/or by gravitational deformation (Figure 2). The major landslide-generated fissures are connected to the slip surfaces existing at different depths and this fissure system drains in a downslope direction through the silt laminae and the locally interbedded sand layers. Because of the pressure head maintained by the perched water in the fissures, one may expect that slip surfaces are following silt and/or sand interfaces (Figure 2). This model is supported by geomorphological observations and geotechnical drillings on several landslides indicating a translational movement in most part with a rotational movement in the upper part (Blanchet, 1988; Jongmans et al., 2009; 
Van Asch et al., 2009). Vertical flows in the laminated clays can be neglected because of the very low permeability perpendicular to the bedding planes $\left(1 \times 10^{-10} \mathrm{~m} / \mathrm{s}\right.$; Giraud et al., 1991; Vuillermet et al., 1994). Permeability parallel to these planes (on the order of $10^{-8}$ to $4 \times 10^{-9} \mathrm{~m} / \mathrm{s}$; Giraud et al., 1991; Vuillermet et al., 1994) is a little lower than the permeability in silt $\left(4 \times 10^{-8} \mathrm{~m} / \mathrm{s}\right.$; Van Asch et al., 1996). The role of the imbricated fissure system then appears predominant for vertical water infiltration and landslide triggering.

The study area is located on the western shore of the artificially-dammed Monteynard lake, which is affected by several large deep-seated gravitational movements, including the Avignonet and Harmalière landslides (Figure 3b). The Digital Elevation Model (DEM) of the Avignonet landslide (Figure 3b), obtained with a Light Detection And Ranging (LiDAR) helicopter acquisition in November 2006, shows the headscarp (at an elevation of about $800 \mathrm{~m}$ ) and the numerous major and minor internal scarps (Figure 3c) affecting the Avignonet landslide that approximately encompasses an area of $1.5 \times 10^{6} \mathrm{~m}^{2}$. Geomorphologic and geodetic data show an increase of the landslide activity downstream, with average displacement rates varying from a few $\mathrm{cm} /$ year below the crest to more than $14 \mathrm{~cm} /$ year at the toe (Jongmans et al., 2009). The study site (about $100 \mathrm{~m}$ by $50 \mathrm{~m}$ in size) is located in the northern part of a small landslide nested at the southern end of the Avignonet landslide (Figure 3b). This eastward moving landslide is bounded to the North by a continuous $1 \mathrm{~m}$ high lateral scarp and to the South by a $1 \mathrm{~m}$ high headscarp which progressively vanishes to the South. The southern limit of the study site is a E-W oriented talweg (Figure 4a). Previous investigation on the Avignonet landslide (Blanchet, 1988), $100 \mathrm{~m}$ north of the study site, has revealed the existence of at least three slip surfaces at about $5 \mathrm{~m}, 10$ to $15 \mathrm{~m}$, and 40 to $48 \mathrm{~m}$ depth.

\section{Investigation methods}

The site was investigated using numerous in-situ and laboratory techniques, to determine the geological, geotechnical and hydrogeological properties of the ground and to characterize fissures. Experiments conducted for this work were spread along two years (see Table 1). Experiments started with 4 drillings, which were conducted between October 2007 and April 2008, and ended with electrical measurements in December 2009. One electrical profile (EP2) and one seismic profile (SP) were monitored. The location of the drillings, of the geophysical profiles and of the GPS points can be seen in figure 4 . Most laboratory tests, logging tools and hydrogeological measurements are classical and only the specific geophysical techniques are described in this section.

Three geophysical methods were applied to physically characterize the studied zone: electrical resistivity tomography (ERT), S-wave seismic refraction tomography and seismic down-hole tests.

ERT is a technique providing $2 \mathrm{D}$ or $3 \mathrm{D}$ images of the ground electrical resistivity. Resistivity values are mainly controlled by the mineralogy of the particles, the ground water content and the nature of the electrolyte (Reynolds, 1997). Open fissures create a high electrical contrast in the ground and ERT was successfully applied in favourable cases, both in the laboratory (Samouëlian et al., 2003) and in the field (Amidu and Dunbar, 2007). However, as discussed by Tabbagh et al. (2007), the fissure position and geometry remain difficult to assess owing to their thin planar feature. Two E-W oriented 
ERT profiles (labelled EP1 and EP2 in Figure 4a) were conducted using the Wenner configuration with 64 electrodes $1 \mathrm{~m}$ apart. Apparent resistivity data were inverted with the algorithm developed by Loke and Barker (1996) using a robust smoothness constrain which minimises absolute changes in resisivity (Loke, 1999).

On the other hand, time-lapse resistivity measurements were found to be successful to detect water content variations less than a few percents within unsaturated media (see for instance Binley et al., 2002; Michot et al., 2003; Schwartz et al., 2008; Clément et al., 2009), provided that the influence of temperature is considered (French and Binley, 2004; Samouëlian et al., 2005; Amidu and Dunbar, 2007). Time-lapse electrical measurements were then performed along profile EP2 with a higher resolution and a similar protocol (64 electrodes $0.5 \mathrm{~m}$ apart in a Wenner configuration) to detect resistivity variations due to water content variations. The resistivities measured in December 2009 were temperature-corrected relative to August in order to assess the SWC changes only. The soil temperatures measured in August (the reference resistivity image) and in December 2009 are $20^{\circ} \mathrm{C}$ and $6^{\circ} \mathrm{C}$ at $0.25 \mathrm{~m}$ depth, respectively, while they are in equilibrium at $3 \mathrm{~m}$ depth. For this temperature range, we chose a linear law to correct restivity values ( $2 \%$ increase of resistivity per $1^{\circ} \mathrm{C}$ decrease of the temperature; Michot et al., 2003).

A seismic refraction profile was performed to determine S-wave velocities (profile SP; Figure 4a). Previous geophysical profiles conducted to gain information on $\mathrm{P}$-waves have shown to be of little interest because of the presence of the perched water table (Jongmans et al., 2009). On the contrary, S-wave velocity has turned out to be closely linked to the deformation state of the clayey material. S-wave velocity was measured using down-hole tests and SH-wave refraction tomography. The S-wave refraction profile was conducted with 24 horizontal $4.5 \mathrm{~Hz}$ geophones $2.5 \mathrm{~m}$ apart. Horizontal shear ( $\mathrm{SH}$ ) waves were generated by hitting a plank oriented perpendicular to the profile. SH-wave first arrival times recorded for 13 source positions were picked and inverted using the Simultaneous Iterative Reconstruction Technique (SIRT; Dines and Lyttle, 1979).

Surface waves are likely to be affected by the presence of open fissures. As shown by Hévin et al. (1998) in concrete, Rayleigh waves are low-pass filtered by surface fissures, at a cut-off frequency $\mathrm{Fc}$ that depends on the ratio between the Rayleigh wave velocity $\mathrm{Vr}$ and the fissure depth Dc. They determined Fc by computing the spectral ratios between the transmitted and incident waves, which exhibit a significant decay over Fc. They found the relation $\mathrm{Fc}=\mathrm{Vr} / 3 \mathrm{Dc}$, which was numerically and experimentally validated. This method was used for detecting fissures in the clay. Rayleigh waves were recorded with 24 vertical $4.5 \mathrm{~Hz}$ geophones $2.5 \mathrm{~m}$ apart along the same profile $\mathrm{SP}$, using a hammer hitting a plate as a source.

\section{Site characterization}

\subsection{Morphological and geotechnical investigation}

A detailed mapping of the fissures and scarps affecting the site was established using the aerial LiDAR DEM (2 $\mathrm{m}$ grid cell size) acquired in November 2006 and a Global Positioning System (GPS) ground survey. Most of these fissures are N-S orientated, perpendicular to the slide movement, with lengths varying between a few dm to $10 \mathrm{~m}$ (Figure 4a). An E-W cross-section through the study site (Figure 4b) shows a progressive decrease in the slope angle from $16^{\circ}$ at the top to almost $0^{\circ}$ at the toe. Most of the 
scarps and fissures are located in the upper and middle parts of the slope, where the slope angle is higher. Two half-meter-high internal scarps (S5, S12; Figure 4) are visible and associated with counterslopes and small sag ponds. In the eastern flat part of the section, fissures are less numerous and the surface is marked by small bulges and hummocks. In January 2009, several $\mathrm{cm}$-wide and m-long tension fissures developed in the upper part of the slide, mainly along a curved line (Figure 4), partly parallel to the headscarp. Two of them exhibit a vertical displacement with a maximum value of $10 \mathrm{~cm}$.

A $49 \mathrm{~m}$ deep borehole (labelled D1 in Figure 4) was cored, allowing the lithological and geotechnical site characteristics to be studied. The geological log (Figure 5) shows the presence of a shallow $2.5 \mathrm{~m}$ thick morainic colluvium layer overlying $16 \mathrm{~m}$ of non-laminated blocky clays made of a matrix of yellowish to grey-black clays containing centimetric to decimetric blocks of limestone and endogenous rocks. Interbedded in these blocky clays are three pluridecimetric to metric layers of laminated clays (depths from top to bottom: $2.5 \mathrm{~m}$ to $3 \mathrm{~m}, 4 \mathrm{~m}$ to $5 \mathrm{~m}$, and $10.8 \mathrm{~m}$ to $11.5 \mathrm{~m}$; Figure 5 ). Below $18.5 \mathrm{~m}$ was found a thick layer of laminated clays. The mean core recovery was $88 \%$ with two missing levels (from $8 \mathrm{~m}$ to $10 \mathrm{~m}$ and from $14 \mathrm{~m}$ to $15 \mathrm{~m}$ ) probably corresponding to disrupted soils. Two sheared zones (a few $\mathrm{cm}$ thick) were identified in laminated clays at depths of 5 and $42 \mathrm{~m}$. Core examination suggests that bedding-parallel shearing occurred within silt layers. These depth values are consistent with the two slip surfaces found at $5 \mathrm{~m}$ and $40 \mathrm{~m}$ in boreholes located $100 \mathrm{~m}$ north of the site (Blanchet, 1988). The intermediate slip surface evinced at about $10 \mathrm{~m}$ to $14 \mathrm{~m}$ depth was not identified in the log but could fit with one or the two unrecovered levels. This point will be discussed further.

Gamma-Ray (GR) logging was performed in borehole D1 and magnetic susceptibility (MS) measurements were made every $2 \mathrm{~cm}$ on the core samples using a Bartington MS2 meter. Results are shown in Figure 5. In the geological context of the Trièves area, the natural gamma radiation is mainly an indicator of the clay content (the higher the clay content, the higher the gamma radiation), while MS measurements denote the presence of magnetic minerals (Verosub, 2000). MS signal in sediments is influenced by numerous factors such as the magnetic mineral content, the grain size and geochemical processes (Rolph et al., 2004). The two curves exhibit a major change (decrease in MS, increase in natural radiation) at the $18.5 \mathrm{~m}$ interface between blocky and laminated clays. In the lower laminated clay layer, MS signal keeps a low constant value $\left(20 \times 10^{-5}\right.$ SI $)$ while the GR signal slightly increases with depth, indicating an augmentation of the clay content to the hole bottom. The blocky clay layer exhibits fluctuating MS values (between 20 and $60 \times 10^{-5} \mathrm{SI}$ ), probably resulting from the presence of endogenous rock pebbles. Within this layer, the laminated clay levels are clearly detected by a low MS value and a high GR signal. The GR peak at $8-10 \mathrm{~m}$ indicates that this unrecovered level is probably made of laminated clays. The constant decrease in GR values observed between $11.5 \mathrm{~m}$ and $18.5 \mathrm{~m}$ is related with high MS values, indicating the increase of grain size with depth. Finally, the relative strong GR radiation in the morainic colluvium indicates a high clay content in this cover layer.

Acoustic borehole imaging $(\mathrm{ABI})$ and temperature logging were conducted in August 2009 within boreholes D2 and D3 (location in Figure 4) whose casings were sealed to the ground in March 2008 (Table 1). ABI results are presented as horizontal cross-sections at some representative depth values in Figure 6. Undeformed casing is shown as a centred 
circle. ABI logging indicates a strong casing deformation at $10.3 \mathrm{~m}$ depth, which could be related to the unrecovered level at the same depth in D1. A smaller deformation is also visible at $5 \mathrm{~m}$ depth (small shift towards the East; Figure 6). Logging in borehole D3 was impossible below $5 \mathrm{~m}$, owing to a casing breakage at that depth (1.5 year after the borehole was drilled and cased; Table 1). Temperature logging in D1 (Figure 6) shows a thermal gradient from 8 to $16 \mathrm{~m}$ depth. A positive temperature anomaly of about $0.1^{\circ} \mathrm{C}$ is observed at $10.3 \mathrm{~m}$ depth, where the casing is strongly deformed. The temperature anomaly probably results from a water flow and these observations suggest the presence of an active slip surface serving as water path at this depth. The slip surface at $5 \mathrm{~m}$ was observed in the three boreholes D1, D2 and D3.

Unconfined and Undrained Shear Strength (USS) tests $0.1 \mathrm{~m}$ apart were carried out in clay cores of borehole D1 using a pocket vane tester. Measured values (Figure 5) allow the material strength to be grossly estimated and compared along the hole. Highly variable shear strengths, ranging from 35 to $200 \mathrm{kPa}$ with a mean value of $115 \mathrm{kPa}$ and a standard deviation (SD) of $40 \mathrm{kPa}$, were observed, denoting the geotechnical heterogeneity along the clay sequence. The lowest values (around $35 \mathrm{kPa}$ ) were found at the two recovered levels (5 and $42 \mathrm{~m}$ ) where shear zones were identified (Figure 5).

Classical laboratory geotechnical tests (bulk density, SWC) were performed on samples from drilling D1 with a spacing of $0.5 \mathrm{~m}$. Porosity and void ratio values were computed and results are gathered by geological layer in table 2. The layers of blocky and laminated clays exhibit similar values with a bulk density around 1.96 and a porosity of about $40 \%$. The comparison between the water content and the porosity values below $2.5 \mathrm{~m}$ (Figure 2) indicates that the clay is saturated or nearly saturated. Of particular interest are the measurements in the two sheared zones. In the deep one $(42 \mathrm{~m})$, the bulk density is close to the one of the surrounding material, with a slightly higher porosity. On the contrary, the superficial shear zone at a depth of $5 \mathrm{~m}$ is characterized by significant lower density (1.74) and higher porosity (48\%). Higher porosity values are also observed in the unsaturated morainic colluvium layer. Atterberg limits were measured on 5 clay samples from the 5 shallowest meters and average plastic (PL) and liquid limits (WL) of $24 \%$ and $46 \%$ were determined, respectively, yielding a plastic index of $22 \%$. Antoine et al. (1981) already found such a relative low plastic index, which explains how the liquid limit could be rapidly reached in this material.

To summarize, geological and geotechnical observations at the study site consistently showed the presence of three slip surfaces within the laminated clays, at depths of $5 \mathrm{~m}$, $10 \mathrm{~m}$ to $15 \mathrm{~m}$ and $42 \mathrm{~m}$. The deepest slip surface is probably linked to the motion of the large Avignonet landslide, in agreement with previous inclinometer data (Jongmans et al., 2009). The two superficial slip surfaces (at $5 \mathrm{~m}$ and $10-15 \mathrm{~m}$ ) seem to be active, as shown by the casing breakage in D3 and the casing deformations in D2. Results also suggest that water infiltrates in the ground through these two slip surfaces, as shown by the temperature anomaly at $10.3 \mathrm{~m}$ in D2 and the high porosity and saturation values found at $5 \mathrm{~m}$ in $\mathrm{D} 1$. 


\subsection{Hydrogeological data}

The permanent meteorological station close to the site (point G in Figure 4a) recorded an annual water precipitation of $700 \mathrm{~mm}$ between July 2008 and July 2009, with main events occurring in summer 2008 (Figure 7c). Five SWC probes using the Time Domain Reflectometry (TDR) technique were set vertically in January 2009, within 5 distinct boreholes $0.5 \mathrm{~m}$ apart, at varying depths $(0.25 \mathrm{~m}, 0.5 \mathrm{~m}, 1 \mathrm{~m}, 2 \mathrm{~m}$, and $3 \mathrm{~m})$ close to drilling D4 (black-filled rectangle in Figure 4). In parallel, seven temperature probes were set into the soil, close to TDR probes, and at different depths $(0.25 \mathrm{~m}, 0.5 \mathrm{~m}, 0.75 \mathrm{~m}, 1 \mathrm{~m}, 1.25 \mathrm{~m}$, $2 \mathrm{~m}$, and $3 \mathrm{~m}$ ) Boreholes were conducted with a manual auger which allowed the soil to be analyzed. TDR probes were set within a clay-silt matrix $(21 \%$ of clays, $71 \%$ of silts and $8 \%$ coarser than $50 \mu \mathrm{m})$ except at $1 \mathrm{~m}$ depth, where the matrix is coarser $(14 \%$ of clays, $41 \%$ of silts and $45 \%$ coarser than $50 \mu \mathrm{m})$. This level, which is enriched in coarse sands and gravels, reveals a local vertical heterogeneity within the morainic colluvium. The objective with the TDR probes was to record the soil water content evolution with time from the surface down to the saturated soil. SWC values were obtained by applying the empirical relationship proposed by Topp et al. (1980). Results are presented as SWC volumetric values in Figure $7 \mathrm{~b}$. The curves indicate that rainfalls had a direct and quick effect on SWC in the first meter of the ground (Figure $7 \mathrm{~b}$ ). SWC values at $1 \mathrm{~m}$ depth are lower than the others, probably as a result from the detected coarser grain size which could induce laterally higher water flow. Below $1 \mathrm{~m}$, TDR probes did not react to rainfall events and record long-term variations of the SWC (TDR probe at $3 \mathrm{~m}$ depth was set into the water table). However, since April 2009, the three uppermost TDR probes exhibit little reaction to rainfall, with a decrease in SWC that is particularly significant for the first meter below surface. Along with less frequent rain events, this behaviour suggests an increased evapotranspiration in summer, leading to drying and hardening the upper soil which would be likely to prevent from water infiltration through the soil matrix (Hillel, 1998). Since the beginning of October 2009, the perched water table level is located below $3 \mathrm{~m}$ depth, in agreement with the TDR probe set at this depth and which reveals a SWC below saturation (saturation is reached for a SWC of $44 \%$; Figure $7 \mathrm{~b}$ and $7 \mathrm{c}$ ). The observed fall of the water table level during summer 2009 did not occur during summer 2008. This may be linked to the lower rain quantity in summer 2009 (Figure 7c). From this and since the water table was higher in summer 2008, it may be inferred that the SWC above water table was more important in summer 2008 (when TDR probes were not set) than in summer 2009.

The study of the SWC evolution for specific precipitation events during summer and winter 2008 indicates a quick increase only a few hours after rain fall for the first meter below surface (infiltration rates of an order of $7 \times 10^{-5} \mathrm{~m} / \mathrm{s}$ and $3 \times 10^{-5} \mathrm{~m} / \mathrm{s}$ in summer and winter, respectively). After the rain fall, the SWC quickly decreases with time, indicating a relatively fast water transit in the medium (same order of decrease rate as for the increase). Permeability values previously determined in saturated silts (highest permeable soil found in situ) are low $\left(4 \times 10^{-8} \mathrm{~m} / \mathrm{s}\right.$; Van Asch et al., 1996) and infiltration rates in unsaturated soil should be even slower (Hillel, 1998). Then, the observed rapid motions can not result from a transit within a clayey matrix and have to be linked to preferential vertical paths like fissures. These observations are consistent with previous works by Topp and Davis (1981) who observed discrepancies in wetting motions between a profile of soil affected by cracks and a profile located at some distance of the cracks. 
Two pore pressure probes were installed at the bottom of borehole D1 $(47 \mathrm{~m})$ and in borehole D4 at a depth of $5 \mathrm{~m}$ (Figure 4a). They are both located within saturated layers and measure the variations of hydrostatic levels with time. During the first three months, piezometric records (Figure 7c) show the presence of two distinct water tables at about $25 \mathrm{~m}$ in D1 and at $2.5 \mathrm{~m}$ in D4. However, since the end of October 2008, the pressure probe in D1 seems to have been damaged and does not work properly. The shallower water table measured in drilling D4 is probably perched in the upper part of the blocky clays and the morainic cover. Water level fluctuations are well correlated with rain events (Figure 7c). The water level first increased of about $20 \mathrm{~cm}$ with the heavy rain falls of Summer 2008, and then regularly decreased of $40 \mathrm{~cm}$ till February 2009 before stabilizing at $686.2 \mathrm{~m}(2.4 \mathrm{~m}$ below the ground level). In summer and fall, the water table continuously deepened by almost $2 \mathrm{~m}$ from July to December 2009 (Figure 7c), reaching the elevation of $684.4 \mathrm{~m}(4.2 \mathrm{~m}$ below the ground level). SWC values indicate that this decrease started in May 2009 for the TDR probe at $0.25 \mathrm{~m}$ depth and in October 2009 for the deepest $(3 \mathrm{~m})$ one. SWC at that depth decreased from 44 to $40 \%$, suggesting that the soil is no more saturated (see Figure 7b). This is consistent with the water table level decrease which was located deeper than $3 \mathrm{~m}$ (elevation of $685.6 \mathrm{~m}$; Figure $7 \mathrm{c}$ ) at the same time.

Water level variations, related to specific rain events, yield an infiltration velocity of an order of $7 \times 10^{-5} \mathrm{~m} / \mathrm{s}$ and $3 \times 10^{-5} \mathrm{~m} / \mathrm{s}$ in summer and winter, respectively. These values are at least 2 order of magnitude higher than those measured in silt levels $\left(4 \times 10^{-8} \mathrm{~m} / \mathrm{s}\right.$; Van Asch et al., 1996), indicating the existence of vertical preferential paths to the water table in the ground.

As a synthesis, hydrogeological data show the presence of two water tables $(2.5 \mathrm{~m}$ to $4 \mathrm{~m}$ deep and $25 \mathrm{~m}$ deep), with the shallowest one probably perched into the upper part of the blocky clays and the morainic cover. Infiltration velocity values for the first three meters below surface, determined through TDR and pressure cell measurements, put forward the fissure network as a preferential vertical infiltration path. Measured rates are of similar order of magnitude in winter and summer. This suggests that these fissures are permanently open. Furthermore, infiltration velocity values are slightly higher in summer than in winter, which could signify a wider opening at the surface resulting from shrinkage.

\subsection{Displacement measurements}

Surface displacements were measured with a GPS at 9 stations installed in July 2008 and labelled G1 to G9 (Figure 7a; location in Figure 4). A permanent GPS station located out of the small landslide (labelled $\mathrm{G}$ in Figure 4a) was used as a reference. It measures the displacement rate of the Avignonet landslide, which was about $3 \mathrm{~cm} /$ year towards the East in 2008. Two time series were taken at the dates of September 2008 and September 2009. Displacements (Figure 7a), which are all oriented towards the East, exhibit contrasting values. Station G9, which is located in contact with the western boundary of the small landslide (Figure 4), shows a displacement around $0.1 \mathrm{~m}$, with a significant downward component. In the upper part of the slope, displacements exhibit an increase from G8 $(0.3 \mathrm{~m})$ to G6 $(0.5 \mathrm{~m})$, with a regular downward motion. Most new open fissures appeared in this area in January 2009 (Figure 4). The highest motion occurred at G5 $(0.8 \mathrm{~m})$ with a prominent vertical component. At G4, the displacement is still 
important $(0.6 \mathrm{~m})$ with a slight upward motion, suggesting a rotation along S10 or S11 (Figure 7a). This is consistent with the casing breakage observed at $5 \mathrm{~m}$ in D3. Beyond this station, displacement values decrease from $0.15 \mathrm{~m}$ to $0.1 \mathrm{~m}$ at the slope bottom.

\subsection{Geophysical results}

The electrical image along EP1, obtained after 3 iterations with an absolute error of $3.4 \%$, is shown in Figure 8a. It is characterized by a rather homogeneous low resistivity (between 15 and $25 \Omega . \mathrm{m}$ ), corresponding to the saturated or nearly saturated blocky clays (Figure 5). Higher values (up to $100 \Omega$.m) are observed in the shallow unsaturated morainic layer. A conductive lens (with a resistivity below $15 \Omega . \mathrm{m}$ ) is observed at 2 to $4 \mathrm{~m}$ depth in the centre of the profile, below tension fissure T6. To get a better resolution in the shallow layers a second ERT profile centred on the first one was performed using 64 electrodes with a spacing of $0.5 \mathrm{~m}$ (profile EP2; Figure 4a). Data were acquired with the same configuration as for EP1. The better-resolved image, obtained after 3 iterations (absolute error of $4.8 \%$ ), shows a continuous resistive superficial layer (unsaturated morainic colluvium), whose thickness varies from $2 \mathrm{~m}$ uphill to less than $1 \mathrm{~m}$ downslope (Figure 8). Except for the conductive lens in the central part of the image, the resistivity decreases with depth, from $120 \Omega . \mathrm{m}$ at the surface to $20 \Omega . \mathrm{m}$ at $2.5 \mathrm{~m}$ depth in the saturated soil. The conductive lens is better resolved and is located above the water table. It could correspond to a zone with a higher clay or water content in the unsaturated layer. Fissures observed at the surface are not detected.

Results of the refraction profile (SP) are shown in Figure 9. Seismograms recorded for the shot at $0 \mathrm{~m}$ show SH waves and Love surface waves (Figure 9a). The $304 \mathrm{SH}$-wave first arrival times recorded for 13 source positions were picked and inverted using the Simultaneous Iterative Reconstruction Technique (SIRT; Dines and Lyttle, 1979) and a grid cell size of $2.5 \times 2.5 \mathrm{~m}$. The Vs image (Figure $9 \mathrm{~b}$ ), obtained after 8 iterations for a RMS error of $3.71 \%$, shows a vertical velocity increase from $150 \mathrm{~m} / \mathrm{s}$ in the first few meters to more than $500 \mathrm{~m} / \mathrm{s}$, with a stronger gradient between $11 \mathrm{~m}$ and $15 \mathrm{~m}$.

Down-hole tests were performed in drillings D1 and D3 (see location in Figure 4a) with a geophone spacing of $1 \mathrm{~m}$ and a shear source operated at the surface. The two Vs vertical profiles (shown in Figure 9b) also evidenced the contrast from $250 \mathrm{~m} / \mathrm{s}$ to $500 \mathrm{~m} / \mathrm{s}$. This depth interface approximately fits the $10 \mathrm{~m}$ active slip surface found in drilling D2 (Figure 6), as well as the unrecovered levels in D1 (10 m and $15 \mathrm{~m}$; Figure 5). The conjugate action of the two slip surfaces at $5 \mathrm{~m}$ and $10-15 \mathrm{~m}$ has probably damaged the upper ground and significantly lowered the S-wave velocity.

\section{Fissure characterization}

Absolute resistivity images did not detect the fissures seen at the surface and we used time-lapse measurements to map resistivity variations along Profile EP2, which is centered on the low resistivity anomaly located below tension fissure T6 (Figure 8). As mentioned before, time-lapse measurements have been found to be very sensitive to water content variations. Four electrical data sets were selected at the beginning (2008/08/01) and at the end (2008/08/29) of August 2008, in May 2009, and in December 2009. The month of August 2008 was relatively rainy $(0.116 \mathrm{~m}$; Figure $7 \mathrm{c})$ and the water table level rose $0.1 \mathrm{~m}$ (Figure 7c). Between September 2008 and May 2009, the water level slightly deepens 
(about $0.3 \mathrm{~m}$ ), before decreasing by nearly $2 \mathrm{~m}$ in December 2009. Figure 10a shows the three resistivity images obtained after 3 iterations with an absolute error lower than $5 \%$. Very slight changes are observed between the first three images. On the contrary, the temperature-corrected resistivity image of December 2009 shows a sensitive increase within the $2 \mathrm{~m}$ thick upper layer, especially in the upper part of the profile. This probably results from the water table lowering and the subsequent decrease in the soil water content.

The first electrical image (2008/08/01) was taken as a reference starting model for the time-lapse electrical measurements. Figure 10b shows the resistivity changes at the three dates $(2008 / 08 / 29,2009 / 05 / 19$, and 2009/12/10) in terms of resistivity ratio with respect to the reference model (Miller et al., 2008). Between the end and the beginning of August 2008 a significant resistivity drop is observed below the tension fissure T6, with an anomaly shape that can be followed to a depth of at least $2 \mathrm{~m}$ (Figure 10b). A general decrease in resistivity is also seen in the shallow layer of $1 \mathrm{~m}$ thick. This decrease in resistivity is interpreted as an increase of SWC related to the rainfall. On the contrary, the resistivity ratio image between May 2009 and the beginning of August 2008 (Figure 10b) exhibits an increase in resistivity below the tension fissure T6, along with an increase in resistivity in the moste part of the superficial layer. This variation is interpreted as a decrease of SWC between the two periods, in agreement with the lower water table level in May 2009 (Figure 7c). The resistivity ratio image between August 2008 and December 2009 exhibits a strong resistivity increase within the first $2 \mathrm{~m}$ along the whole profile (Figure 10b, which is interpreted as a general SWC decrease in the soil layer, in agreement with water levels and SWC variations (Figure 7b and 7c). This global effect probably masks some fissureinduced variations, particularly below T6. However, a local resisitivity decrease is clearly shown in May and December 2009 below the scarp S5, which did not appear at the end of August 2008. All these results suggest that fissures could evolve with time and exhibit resistivity variations linked to their water storage capacity.

We then tried to determinate the characteristics of these fissures using surface waves recorded during refraction tests along profile SP. As shown by Hévin et al. (1998) in concrete, Rayleigh waves are low-pass filtered by surface fissures, at a cut-off frequency Fc that depends on the ratio between the Rayleigh wave velocity $\mathrm{Vr}$ and the fissure depth Dc. They determined Fc by computing the spectral ratios between the transmitted and incident waves, which exhibit a significant decay over Fc. They found the relation $\mathrm{Fc}=\mathrm{Vr} / 3 \mathrm{Dc}$, which was numerically and experimentally validated. We applied this procedure to four shots performed at the western end of the profile SP (end shot at $0 \mathrm{~m}$ and offset shot at $-20 \mathrm{~m}$ ) for two different dates (January 2009 and July 2009). Measurements were conducted with 24 vertical $4.5 \mathrm{~Hz}$ geophones $2.5 \mathrm{~m}$ apart. Figure $11 \mathrm{a}$ shows the normalized seismograms of one of these shots, which exhibit energetic Rayleigh waves. The dispersion curve of the Rayleigh waves, computed for the signals recorded between $15 \mathrm{~m}$ and $35 \mathrm{~m}$, is shown in Figure 11b. The profile crosses several scarps and tension fissures (Figures 4 and 11a), the effect of which on the signals is little visible, except an attenuation of the high frequency Rayleigh waves beyond the scarp S4 at $20 \mathrm{~m}$. The graph of the seismic energy as a function of the distance is plotted in Figure 11c for the four shots. All curves exhibit a significant energy drop (and a further recovery) at distances of $20 \mathrm{~m}$ and to a lesser extent of $35 \mathrm{~m}$, which correspond to fissures $\mathrm{S} 4$ and T6, respectively. Spectral ratios between Rayleigh waves recorded after and before S4 are given in Figure 11d. All curves exhibit decay at a frequency of about $20 \mathrm{~Hz}$. Applying the relation proposed by Hévin et al. (1998), with the Rayleigh wave velocity of $120 \mathrm{~m} / \mathrm{s}$ 
at this frequency (Figure 11b), yields a fissure depth of about $2 \mathrm{~m}$. In the same way, spectral ratios were computed for the tension fissure T6 located at $35 \mathrm{~m}$ (Figure 11e). Curves show decay at a cut-off frequency of around $30 \mathrm{~Hz}$, which gives a fissure depth of about $1.5 \mathrm{~m}$. This value is consistent with the one found with time-lapse ERT below T6 (Figure 10). It must be stressed out that these depth values must be considered as an order of magnitude, as the work of Hévin et al. (1998) was validated for fissures developing in a homogeneous medium. These fissure depths are consistent with the perched water table level, indicating that some fissures observed at the surface could be connected to the water table and then constitute a preferential path for water. No significant difference in the cut-off frequency Fc is observed between the two dates (January and July 2009), suggesting that these fissures were permanently open to this depth.

\section{Synthesis and conclusions}

Geotechnical, geophysical and hydrogeological measurements were conducted to characterize the role of fissures in water infiltration and their link to slip surfaces in a small active landslide in the Trièves area. Three slip surfaces were detected at about $5 \mathrm{~m}, 10 \mathrm{~m}$ to $15 \mathrm{~m}$, and at $42 \mathrm{~m}$ (Figures 5 and 6 ), in agreement with previous studies along a crosssection $100 \mathrm{~m}$ apart (Jongmans et al., 2009). Drilling results showed that two of these slip surfaces are located in laminated clays, and other data suggest that it is probably the case for the third one (Figure 5). These observations highlight the role of silt laminae in water infiltration, which was already underlined by Van Asch et al. (1996) in the Trièves clay. Figure 12 synthesizes the main results obtained in this study along an E-W oriented schematic cross-section showing the upper $15 \mathrm{~m}$ of the slope. As shown by the GPS measurements, the maximum superficial displacement occurred near to drillings D3 and D4 (Figure 7a), consistently with the casing breakage generated by the slip surface at $5 \mathrm{~m}$ in D3. The presence and activity of this slip surface was also attested by the casing deformation in D2 (Figure 6) and the low density, low shear strength, saturated shear zone observed in D1 (Figure 5; Table 2). A second slip surface was evidenced in drilling D2 at about $10 \mathrm{~m}$ depth (Figure 6), where the casing was strongly deformed and water flow was detected by the temperature logging. These observations suggest that slip surfaces follow more permeable (silt) laminae or layers and constitute water paths.

The activity of these two shallow slip surfaces contributed to damage the sliding clay, as shown by the low Vs values $(250 \mathrm{~m} / \mathrm{s}$ and $150 \mathrm{~m} / \mathrm{s}$ on average; Figure 9) measured above the $10 \mathrm{~m}$ surface and the $5 \mathrm{~m}$ surface, respectively. Compared to similar experiments in the same material (Jongmans et al., 2009), these values indicate a strong deformation of the clay. The Vs image, along with the two down-hole experiments (Figure 9b), indicated a deepening of the second slip surface to the East, which could be related with the presence of two unrecovered (low mechanical quality) levels at $10 \mathrm{~m}$ and $15 \mathrm{~m}$ in drilling D1 (Figure 5), suggesting a relay between two slip surfaces (Figure 12).

Hydrogeological results (TDR and pressure cell data; Figure 7), along with previously obtained permeability measurements (Giraud et al., 1991; Vuillermet et al., 1994; Van Asch et al., 1996), showed that vertical preferential water paths are necessary to explain the measured infiltration rates. Among the mapped tension fissures and scarps (Figure 4), surface wave attenuation study pointed out that two of these structures (S4 
and T6; Figure 12) were open at the time of the experiments to a depth of about $2 \mathrm{~m}$ (Figure 11). Time-lapse ERT showed significant variations in resistivity with time below the tension fissure T6 (Figure 10), resulting from water content changes and suggesting that this fissure constitutes a preferential path for water.

These results highlight that fissures affecting the surface may reach, at least, the perched water table at about $2.5 \mathrm{~m}$. Below this level, fissures are no more detectable by the applied geophysical techniques. This probably results from the resolution decrease with depth exhibited by the two geophysical techniques, along with the fissure thinning and the weakness of the resistivity contrasts between the clay and water-filled fissures. However, the whole set of data, including evidence of water flow in D2 at $10 \mathrm{~m}$, suggests that this system of imbricated fissures drains to the slip surfaces at $5 \mathrm{~m}$ and $10-15 \mathrm{~m}$. This put forward the important role played by the fissure network at surface, as preferential infiltration path down to shallow slip surfaces in the numerous clay landslides of the Trièves area.

\section{Acknowledgements}

This work was supported by the European project "Mountain Risks" (Marie Curie program) and funded by numerous French projects: the LCPC Sécheresse program, the ECOUPREF ANR program, the Cluster Environnement (Région Rhône-Alpes), the Cluster VOR (Vulnérabilité des Ouvrages aux Risques) and the Department of Isère through the Pôle Grenoblois des Risques Naturels. The authors thank Y. Orengo and R. Béthoux for their participation to the instrument installation. We also wish to thank two anonymous reviewers for their constructive comments.

\section{References}

Aleotti, P. (2004). A warning system for rainfall-induced shallow failures. Engineering Geology, 73:247-265.

Amidu, S. A. and Dunbar, J. A. (2007). Geoelectric studies of seasonal wetting and drying of a Texas vertisol. Vadose Zone Journal, 6(3):511-523.

Antoine, P., Giraud, A., and Montjuvent, G. (1981). Les argiles litées du Trièves (Isère) ; conditions de gisement et exemples de propriétés géotechniques. Bulletin de la Société Géologique de France, 7, XXIII(2):117-127.

Binley, A., Winship, P., West, L. J., Pokar, M., and Middleton, R. (2002). Seasonal variation of moisture content in unsaturated sandstone inferred from borehole radar and resistivity profiles. Journal of Hydrology, 267(3-4):160-172.

Blanchet, F. (1988). Etude géomécanique de glissements de terrain dans les argiles glaciolacustres de la vallée du Drac. PhD thesis, Université Joseph Fourier, Grenoble, France.

Brocard, G. Y., Van Der Beek, P. A., Bourlès, D. L., Siame, L. L., and Mugnier, J.-L. (2003). Long-term fluvial incision rates and postglacial river relaxation time in the 
French Western Alps from 10Be dating of alluvial terraces with assessment of inheritance, soil development and wind ablation effects. Earth and Planetary Science Letters, 209:197-214.

Chen, C. Y., Chen, T. C., Yu, W. H., and Lin, S. C. (2005). Analysis of time-varying rainfall infiltration induced landslide. Environmental Geology, 48:466-479.

Clément, R., Descloitres, M., Günther, T., Ribolzi, O., and Legchenko, A. (2009). Influence of shallow infiltration on time-lapse ert: Experience of advanced interpretation. Comptes Rendus Geosciences, 341(10-11):886-898.

Comegna, L., Picarelli, L., and Urciuoli, G. (2007). The mechanics of mudslides as a cyclic undrained-drained process. Landslides, 4:217-232.

Corominas, J. (2001). Landslides and climate. In Keynote lectures from the 8th International Symposium on Landslides, volume 4, pages 1-33.

Debelmas, J. (1967). La Chapelle-en-Vercors. In Carte géologique de la France à 1/50000. BRGM Éditions, Orléans, France.

Dines, K. and Lyttle, J. (1979). Computerized geophysical tomographiy. Proceedings of the Institute of Electrical and Electronics Engineers, 67:1065-1073.

French, H. and Binley, A. (2004). Snowmelt infiltration: monitoring temporal and spatial variability using time-lapse electrical resistivity. Journal of Hydrology, 297(1-4):174186.

Giraud, A., Antoine, P., Van Asch, T. W. J., and Nieuwenhuis, J. D. (1991). Geotechnical problems caused by glaciolacustrine clays in the French Alps. Engineering Geology, 31:185-195.

Guzetti, F. (2000). Landslide fatalities and the evaluation of landslide risk in Italy. Engineering Geology, 58(2):89-107.

Gvirtzman, H., Shalev, E., Dahan, O., and Hatzor, Y. (2008). Large-scale infiltration experiments into unsaturated stratified loess sediments: monitoring and modeling. Journal of Hydrology, 349(1-2):214-229.

Hévin, G., Abraham, O., Pedersen, H. A., and Campillo, M. (1998). Characterization of surface cracks with Rayleigh waves: a numerical model. Nondestructive Testing and Evaluation International, 31(4):289-297.

Hillel, D. (1998). Environmental soil physics. Academic Press, San Diego, USA.

Iverson, R. M. (2000). Landslide triggering by rain infiltration. Water Resources Research, 36(7):1897-1910.

Jongmans, D., Bièvre, G., Schwartz, S., Renalier, F., and Beaurez, N. (2009). Geophysical investigation of the large Avignonet landslide in glaciolacustrine clays in the Trièves area (French Alps). Engineering Geology, 109:45-56. 
Krzeminska, D. M., Bogaard, T. A., Debieche, T.-H., Marc, V., Ponton, J., and Malet, J.-P. (2009). Quantitative analysis of preferential flow during small scale infiltration tests on an active mudslide, Super-Sauze, South French Alps. In Proceedings of the International Conference "Landslide processes: from geomorphologic mapping to dynamic modelling", february 2009, Strasbourg, France.

Lindenmaier, F., Ihringer, J., Dittfurth, A., and Zehe, E. (2005). Process identification at a slow moving landslide in the Vorarlberg Alps. Hydrological Processes, 19:1635-1651.

Loke, M. H. (1999). Time-lapse resistivity imaging inversion. In 5th meeting of the Environmental and Engineering Society, European Section, 6-9 september 1999, Budapest, Hungary.

Loke, M. H. and Barker, R. (1996). Rapid least-squares inversion of apparent resistivity pseudosections by a quasi-newton method. Geophysical Prospecting, 44:131-152.

Malet, J.-P., Auzet, A.-V., Maquaire, O., Ambroise, B., Descroix, L., Esteves, M., Vandervaere, J.-P., and Truchet, E. (2003). Soil surface characteristics influence on infiltration in black marls: application to the Super-Sauze earthflow (southern Alps, France). Earth Surface Processes and Landforms, 28(5):547-564.

Meisina, C. (2006). Characterisation of weathered clayey soils responsible for shallow landslides. Natural Hazards and Earth System Sciences, 6(5):825-838.

Michot, D., Benderitter, Y., Dorigny, A., Nicoullaud, B., King, D., and Tabbagh, A. (2003). Spatial and temporal monitoring of soil water content with an irrigated corn crop cover using surface electrical resistivity tomography. Water Resources Research, 39(5):1138.

Miller, C. R., Routh, P. S., Brosten, T. R., and McNamara, J. P. (2008). Application of time-lapse ERT imaging to watershed characterization. Geophysics, 73(3):G7-G17.

Monjuvent, G. (1973). La transfluence Durance-Isère. Essai de synthèse du Quaternaire du bassin du Drac (Alpes françaises). Géologie Alpine, 49:57-118.

Morris, P. H., Graham, J., and Williams, D. J. (1992). Cracking in drying soils. Canadian Geotechnical Journal, 29:263-277.

Moser, M. and Hohensinn, F. (1983). Geotechnical aspects of soil slips in alpine regions. Engineering Geology, 19:185-211.

Nieuwenhuis, J. D. (1991). Variations in stability and displacements of a shallow seasonal landslide in varved clays. PhD thesis, Utrecht University, The Netherlands.

Panizza, M., Pasuto, A., Silvano, S., and Soldati, M. (1996). Time occurrence and activity of landslides in the area of Cortina d'Ampezzo (Dolomites, Italy). Geomorphology, $15: 311-326$.

Picarelli, L., Urciuoli, G., Ramondini, M., and Comegna, L. (2005). Main features of mudslides in tectonised highly fissured clay shales. Landslides, 2(1):15-30.

Picarelli, L., Urciuoli, G., and Russo, C. (2004). The role of groundwater regime on behaviour of clayey slopes. Canadian Geotechnical Journal, 41:467-484. 
Reynolds, J. M. (1997). An introduction to applied and environmental geophysics. Wiley and Sons.

Rolph, T. C., Vigliotti, L., and Oldfield, F. (2004). Mineral magnetism and geomagnetic secular variation of marine and lacustrine sediments from central Italy: timing and nature of local and regional holocene environmental change. Quaternary Science Reviews, 23(14-15):1699-1722.

Samouëlian, A., Cousin, I., Richard, G., Tabbagh, A., and Bruand, A. (2003). Electrical resistivity imaging for detecting soil cracking at the centimetric scale. Soil Science Society of America Journal, 67:1319-1326.

Samouëlian, A., Cousin, I., Tabbagh, A., Bruand, A., and Richard, G. (2005). Electrical resistivity survey in soil science: a review. Soil and Tillage Research, 83(2):173-193.

Schwartz, B. F., Schreiber, M. E., and Yan, T. (2008). Quantifying field-scale soil moisture using electrical resistivity imaging. Journal of Hydrology, 362(3-4):234-246.

Tabbagh, J., Samouelian, A., Tabbagh, A., and Cousin, I. (2007). Numerical modelling of direct current electrical resistivity for the characterisation of cracks in soils. Journal of Applied Geophysics, 62(4):313-323.

Terlien, M. T. J. (1998). The determination of statistical and deterministic hydrological landslide-triggering thresholds. Environmental Geology, 35:124-130.

Tofani, V., Dapporto, S., Vannocci, P., and Casagli, N. (2006). Infiltration, seepage and slope instability mechanisms during the 20-21 November 2000 rainstorm in Tuscany, central Italy. Natural Hazards and Earth System Science, 6(6):1025-1033.

Topp, G. C. and Davis, J. L. (1981). Detecting infiltration of water through soil cracks by time-domain reflectometry. Geoderma, 26(1-2):13-23.

Topp, G. C., Davis, J. L., and Annan, A. P. (1980). Electromagnetic determination of soil water content. measurements in coaxial transmission lines. Water Resources Research, 16(3):574-582.

Tu, X. B., Kwong, A., Dai, F., Tham, L., and Min, H. (2009). Field monitoring of rainfall infiltration in a loess slope and analysis of failure mechanism of rainfall-induced landslides. Engineering Geology, 105:134-150.

Van Asch, T. W. J., Brinkhorst, W. H., Buist, H. J., and Vessem, P. V. (1984). The development of landslides by retrogressive failure in varved clays. Zeitschrift für Geomorphologie N. F., Suppl. -Bd. 4:165-181.

Van Asch, T. W. J., Hendriks, M. R., Hessel, R., and Rappange, F. E. (1996). Hydrological triggering conditions of landslides in varved clays in the French Alps. Engineering Geology, 42:239-251.

Van Asch, T. W. J., Malet, J.-P., and Bogaard, T. A. (2009). The effect of groundwater fluctuations on the velocity pattern of slow-moving landslides. Natural Hazards and Earth System Sciences, 9(3):739-749. 
Van Asch, T. W. J., Malet, J.-P., and Van Beek, L. (2006). Influence of landslide geometry and kinematic deformation to describe the liquefaction of landslides: Some theoretical considerations. Engineering Geology, 88(1-2):59-69.

Van Asch, T. W. J., Van Beek, L. P. H., and Bogaard, T. A. (2007). Problems in predicting the mobility of slow-moving landslides. Engineering Geology, 91:46-55.

Verosub, K. L. (2000). Paleomagnetic dating. In Noller, J. S., Sowers, J. M., and Lettis, W. R., editors, Quaternary methodology - Methods and applications, number 4 in AGU Reference Shelf, pages 339-356. American Geophysical Union, Washington DC, USA.

Vuillermet, E., Cordary, D., and Giraud, A. (1994). Caractéristiques hydrauliques des argiles litées du Trièves (Isère). Bulletin of the International Association of Engineering Geology, 49:85-90.

Wilson, R. C. and Wieczorek, G. F. (1995). Rainfall thresholds for the initiation of debris flows at La Honda, California. Environmental and Engineering Geoscience, 1(1):11-27. 


\begin{tabular}{lll}
\hline Experiment & Date & Characteristics \\
\hline Drilling D1 & $2007 / 10 / 02$ to 2007/10/10 & 49 m deep coring \\
Drilling D4 & $2007 / 10 / 11$ & 5 m deep coring \\
Drillings D2 and D3 & $2008 / 03 / 04$ to 2008/03/10 & 20 m long drillings, with a casing sealed to the ground \\
Geomorphological mapping & $2008 / 03 / 11$ to 2008/03/13 & GPS location of the main geomorphological markers \\
Downhole tests & $2008 / 07 / 02$ & Measurements within D2 and D3 \\
EP1 & $2008 / 07 / 31$ & 64 electrodes, $1 \mathrm{~m}$ apart, in a Wenner configuration \\
EP2 & $2008 / 08 / 01$ & 64 electrodes, $0.5 \mathrm{~m}$ apart, in a Wenner configuration \\
EP2 & $2008 / 08 / 29$ & 64 electrodes, $0.5 \mathrm{~m}$ apart, in a Wenner configuration \\
GPS & $2008 / 09 / 24$ & GPS measurements fo stations G1 to G9 \\
SP & $2009 / 01 / 14$ & 24 geophones $2.5 \mathrm{~m}$ apart \\
Geomorphological mapping & $2009 / 01 / 27$ & GPS location of the new geomorphological markers \\
EP2 & $2009 / 05 / 18$ & 64 electrodes, 0.5 m apart, in a Wenner configuration \\
SP & $2009 / 07 / 31$ & 24 geophones $2.5 \mathrm{~m}$ apart \\
Logging in D2 and D3 & $2009 / 08 / 19$ & Caliper and temperature logging \\
GPS & $2009 / 09 / 10$ & GPS measurements for stations G1 to G9 \\
EP2 & $2009 / 12 / 12$ & 64 electrodes, 0.5 m apart, in a Wenner configuration \\
\hline
\end{tabular}

Table 1: Dates and characteristics of the experiments. See text for details.

\begin{tabular}{ccccccc}
\hline Depth $(\mathrm{m})$ & Unit & $\begin{array}{c}\text { Number of } \\
\text { samples }\end{array}$ & Bulk density & $\begin{array}{c}\text { Volumetric } \\
\text { water content } \\
(\%)\end{array}$ & Porosity (\%) & Void ratio \\
\hline $0-0.5$ & Top soil & 1 & 1.57 & 27.3 & 36.5 & 0.57 \\
$0.5-2.5$ & Morainic colluvium & 6 & $2.02(0.1)$ & $39.85(7.38)$ & $44.6(2.4)$ & $0.81(0.08)$ \\
$2.5-18.5$ & Blocky clays & 21 & $1.95(0.17)$ & $39.41(7.5)$ & $39.47(7.72)$ & $0.68(0.2)$ \\
$18.5-41$ & Slipped laminated clays & 43 & $1.96(0.17)$ & $41.01(4.22)$ & $41.28(4.15)$ & $0.71(0.12)$ \\
$43-49$ & In situ laminated clays & 13 & $1.960 .08)$ & $39.18(2.96)$ & $39.63(2.95)$ & $0.66(0.08)$ \\
5 & Slip surface 1 & 2 & $1.74(0.07)$ & $48.19(0.21)$ & $48.2(0.2)$ & $0.93(0.01)$ \\
42 & Slip surface 2 & 2 & $2(0.01)$ & $41.01(0.76)$ & $43(2.06)$ & $0.76(0.06)$ \\
\hline
\end{tabular}

Table 2: Density and water content values (with standard deviation in parentheses) measured in borehole D1. Only one sample was available for the first $0.5 \mathrm{~m}$. See text for details. 


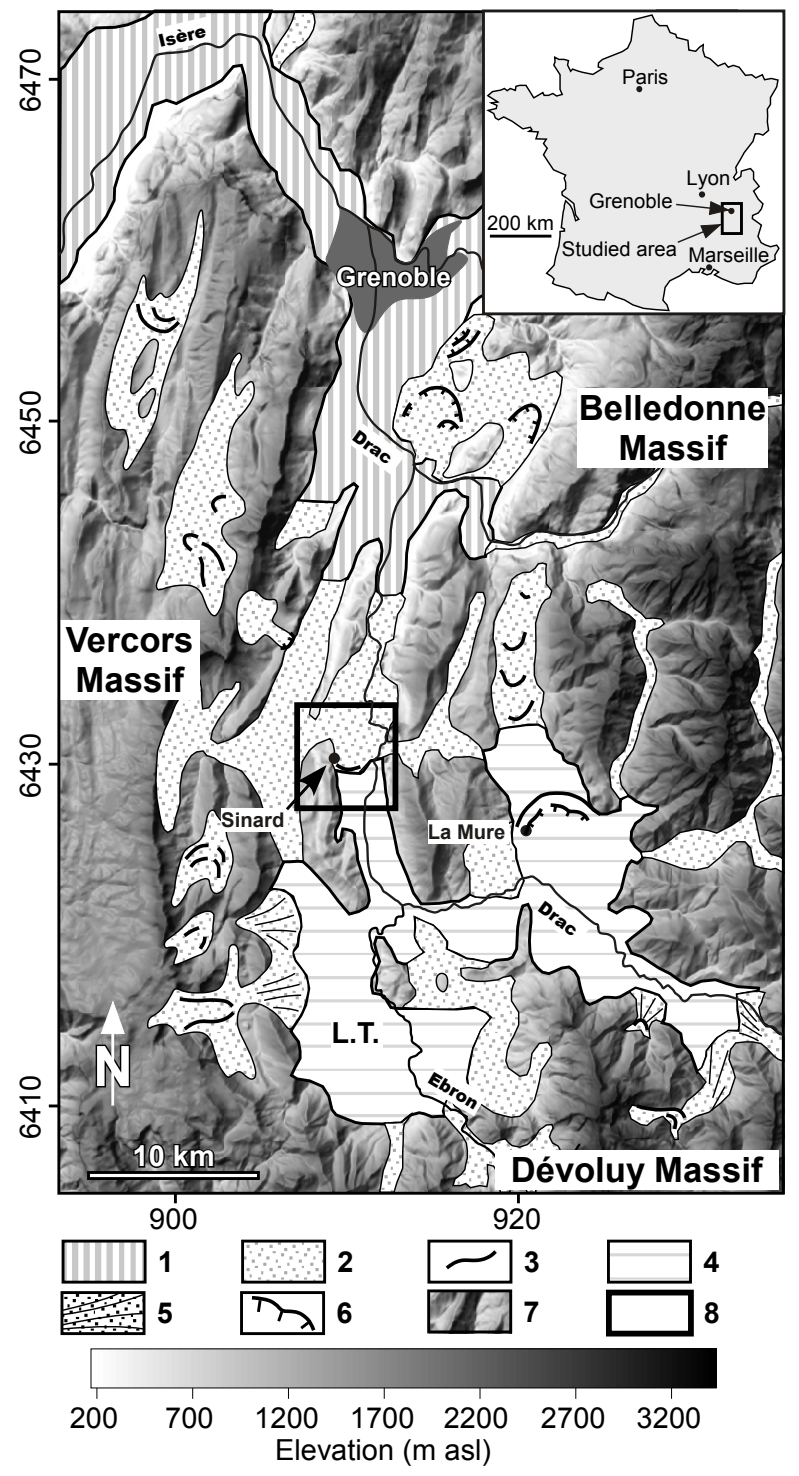

Figure 1: Location of the study area and extension of the different Quaternary facies (modified from Monjuvent, 1973). Coordinates are kilometric according to French system Lambert-93. 1: Alluvial plain of the Drac and Isère rivers. 2: Würmian alluvial and morainic deposits. 3: Morainic arcs (Würm II age). 4: Laminated clays (Würm II age). 5: Glaciolacustrine deltas. 6: Morainic arcs (Würm III age). 7: Present-day topography. 8: Study area. L.T.: Lake Trièves. 


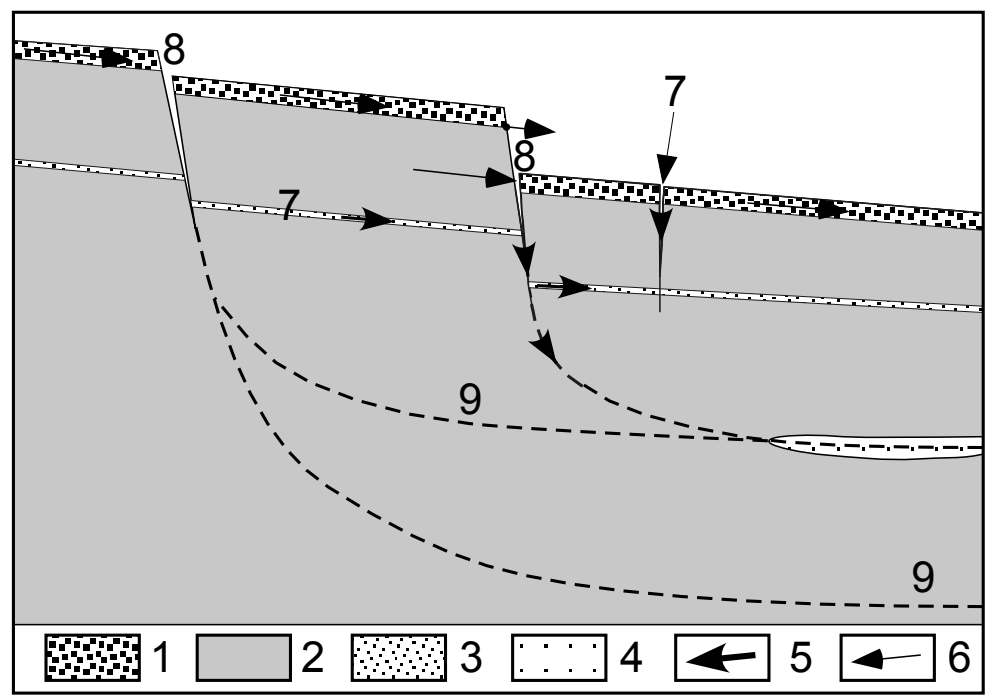

Figure 2: Conceptual framework for water infiltration within slipped and fissured laminated clays (modified from Van Asch et al., 1984; Nieuwenhuis, 1991; Vuillermet et al., 1994). 1: Morainic colluvium. 2: Laminated clays. 3: Silty beds. 4: Sand beds. 5: Water run-off. 6: Epidermic run-off. 7: Tension fissures. 8: Scars and scarps. 9: Slip surface.


Figure 3: Geological and geomorphological context and location of the study site in the regional geological framework. a) Geological map of the area (adapted from Debelmas, 1967). Morainic colluvium has not been reported. Coordinates are kilometric according to French system Lambert-93. A: Avignonet landslide. H: Harmalière landslide. b) LiDAR DEM morphology. c) Geomorphological mapping of the main scarps of the Avignonet landslide. 

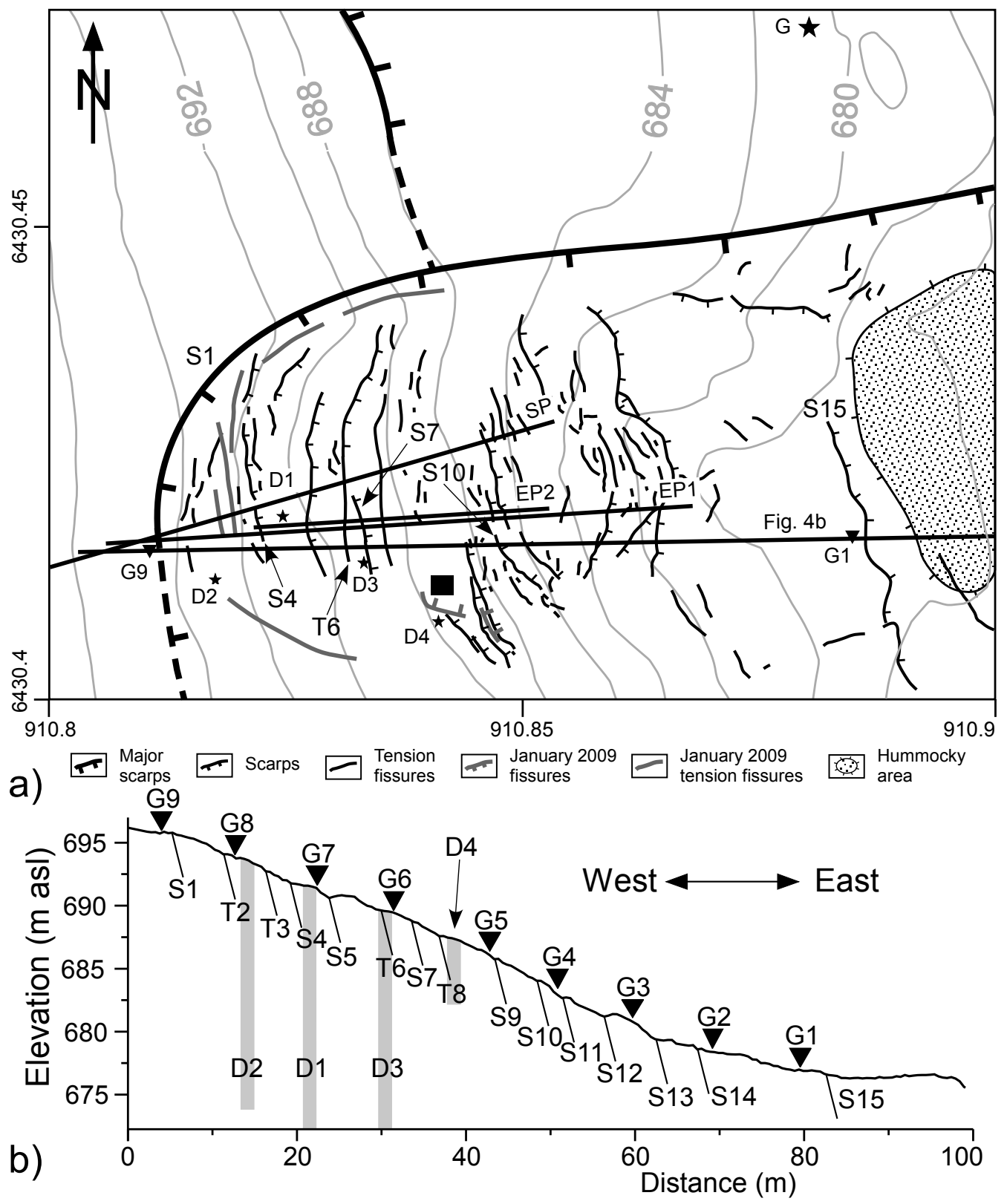

Figure 4: Geomorphological mapping of the study site and location of the geophysical measurements. a) Topographic map with location of scarps, tension fissures and hummocky areas. G: GPS reference station and meteorological station. SP: seismic profile; EP1 and EP2: electrical resistivity profile; D1 to D4: boreholes. S1 to S15: scarps (location in Figure 4b); T6: tension fissure (location in Figure 4b). Black-filled rectangle corresponds to SWC probes location. b) E-W cross-section of the site along GPS points (location in Figure 4a) with position of main scarps (S) and tension fissures (T). G1 to G9: GPS points. 


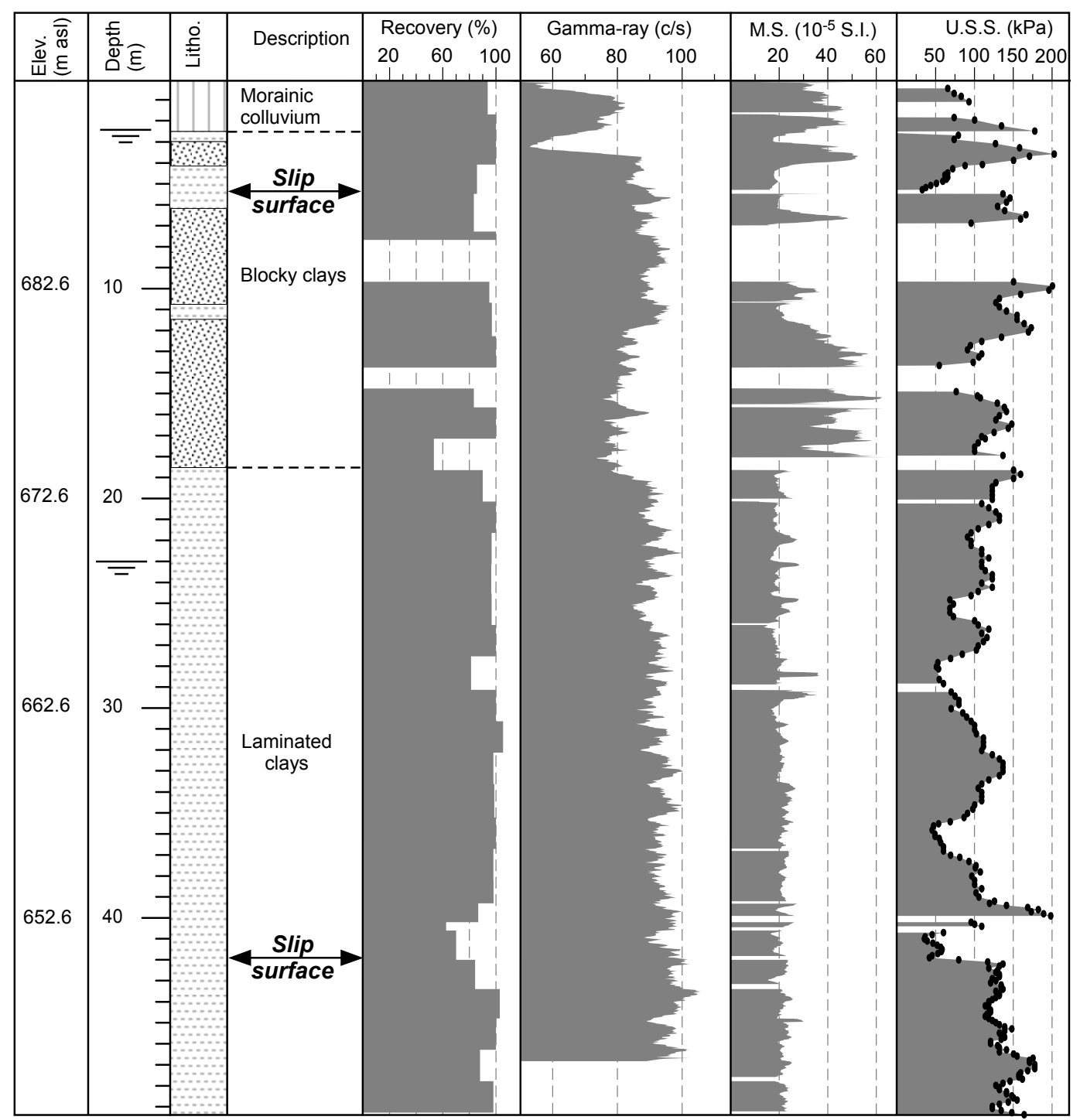

Figure 5: Geotechnical log of borehole D1 (location in Figure 4a). M.S.: Magnetic susceptibility. U.S.S.: Unconfined and undrained shear strength, where black dots stand for measurement points. 


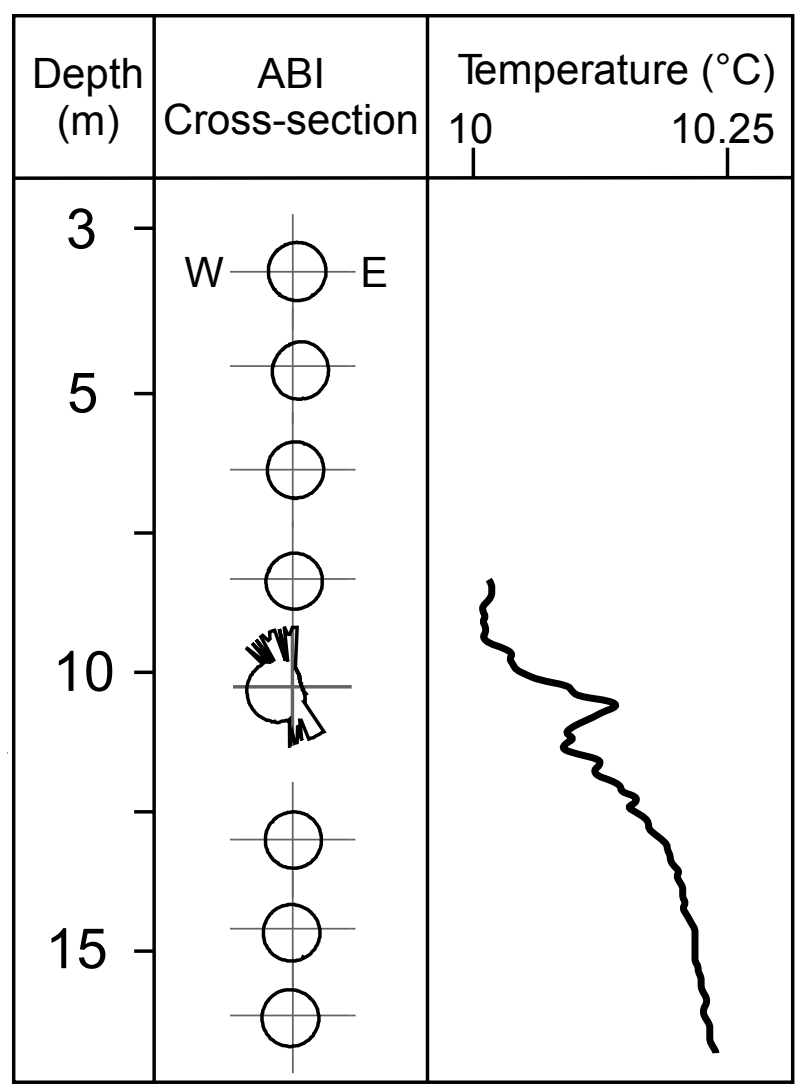

Figure 6: Acsoustic Borehole Imaging (ABI) and temperature logging in borehole D2 (location in Figure 4a). 

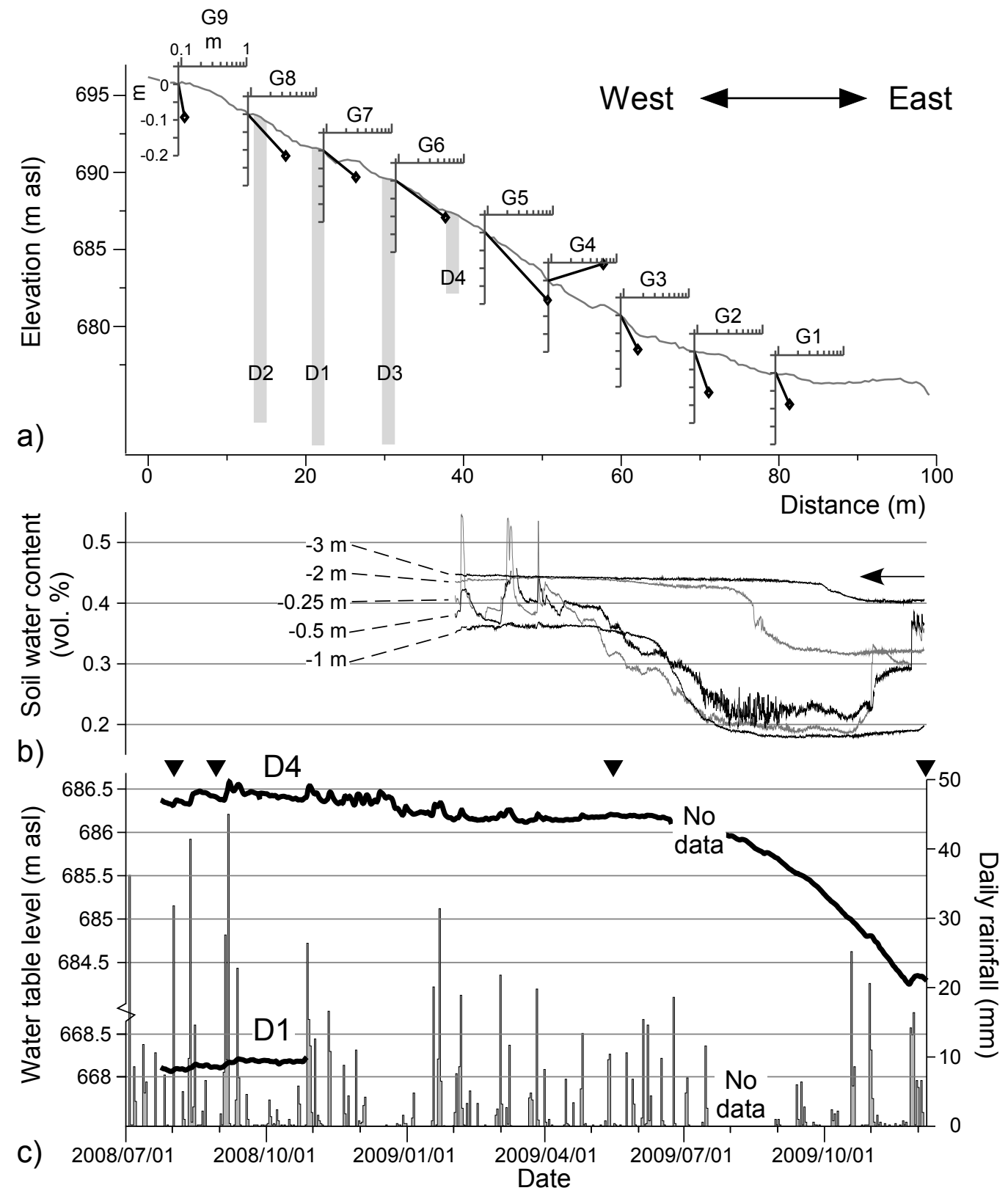

Figure 7: Ground and meteorological parameters of the study site over a one year and half period. a) Displacement rates for GPS points G1 to G9 (location in Figure 4) between september 2008 and september 2009; vertical and horizontal scales are in meter. b) SWC derived from TDR measurements. Arrow indicates saturation value (44\%) at $3 \mathrm{~m}$ depth. c) Water table level for piezometers D1 and D4 (location in Figure 4b) and daily rainfall time series. Black triangles indicate the dates of ERT measurements (profile EP2). 


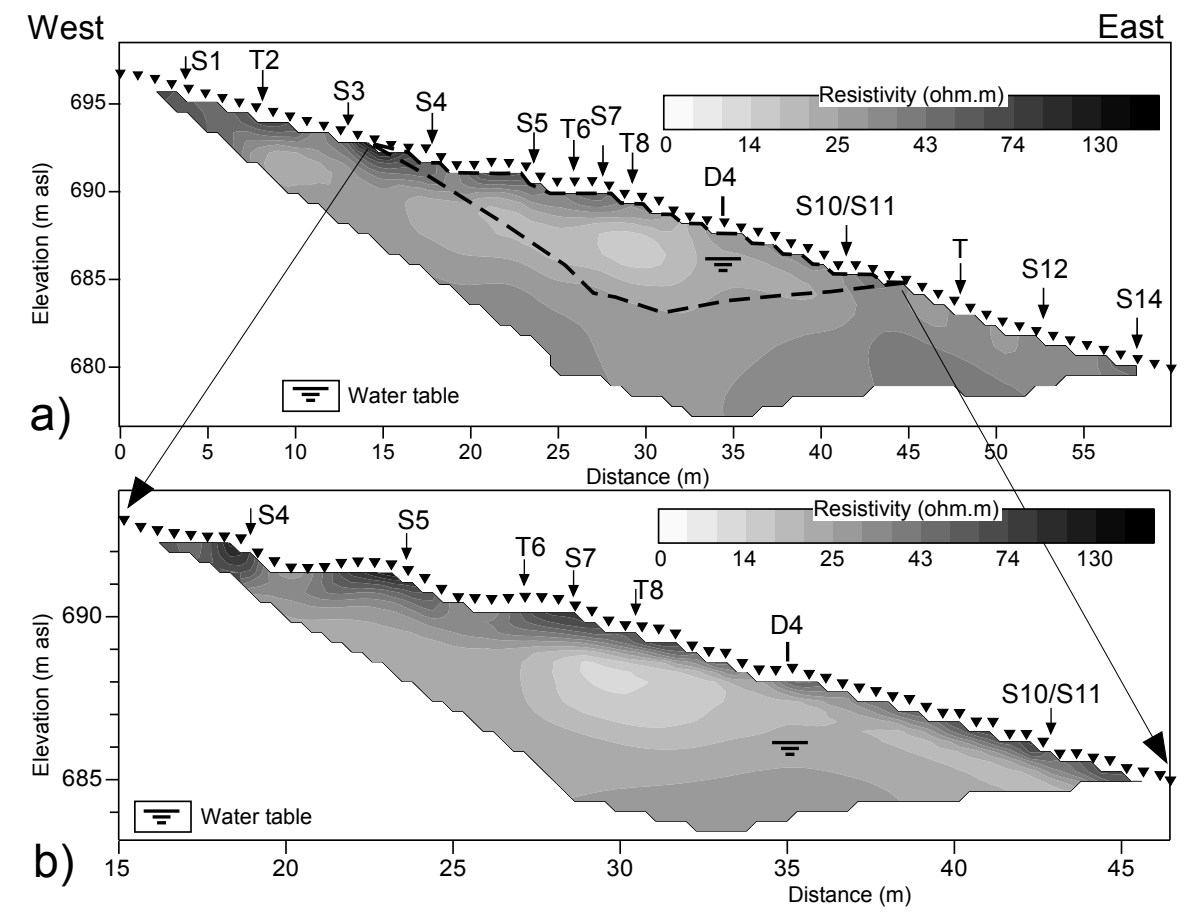

Figure 8: Electrical resistivity tomography. Profiles were acquired with 64 electrodes in a Wenner configuration. S: scarps; T: tension fissures. a) Profile EP1 conducted on 2008/07/31 (location in Figure 4a) with $1 \mathrm{~m}$ electrode spacing. Absolute error is $3.4 \%$ after 3 iterations. b) Profile EP2 conducted on 2008/08/01 (location in Figure 4a) with $0.5 \mathrm{~m}$ electrode spacing. Absolute error is $4.8 \%$ after 3 iterations. Water table level within borehole D4 is indicated.
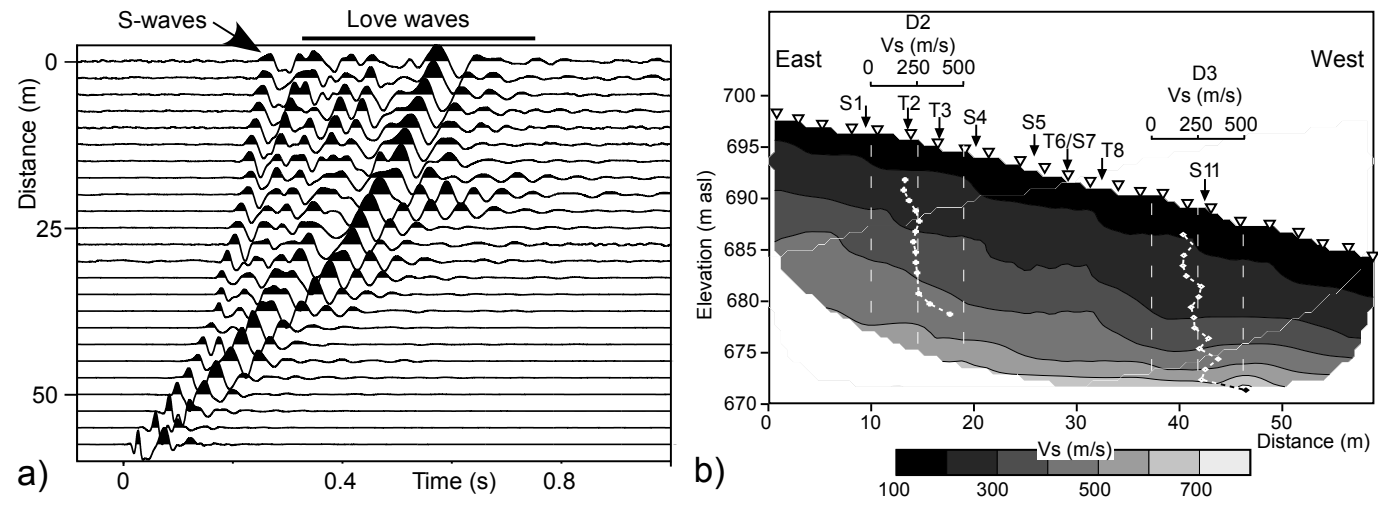

Figure 9: S-wave velocity imaging along profile SP (location in Figure 4a). a) Seismograms showing S-waves and Love surface waves. b) S-wave refraction tomography for 24 surface geophones and 12 sources regularly spread along the profile; RMS is $3.71 \%$ after 8 iterations. Vs vertical profiles derived from down-hole tests in boreholes D2 and D3 are superimposed. 


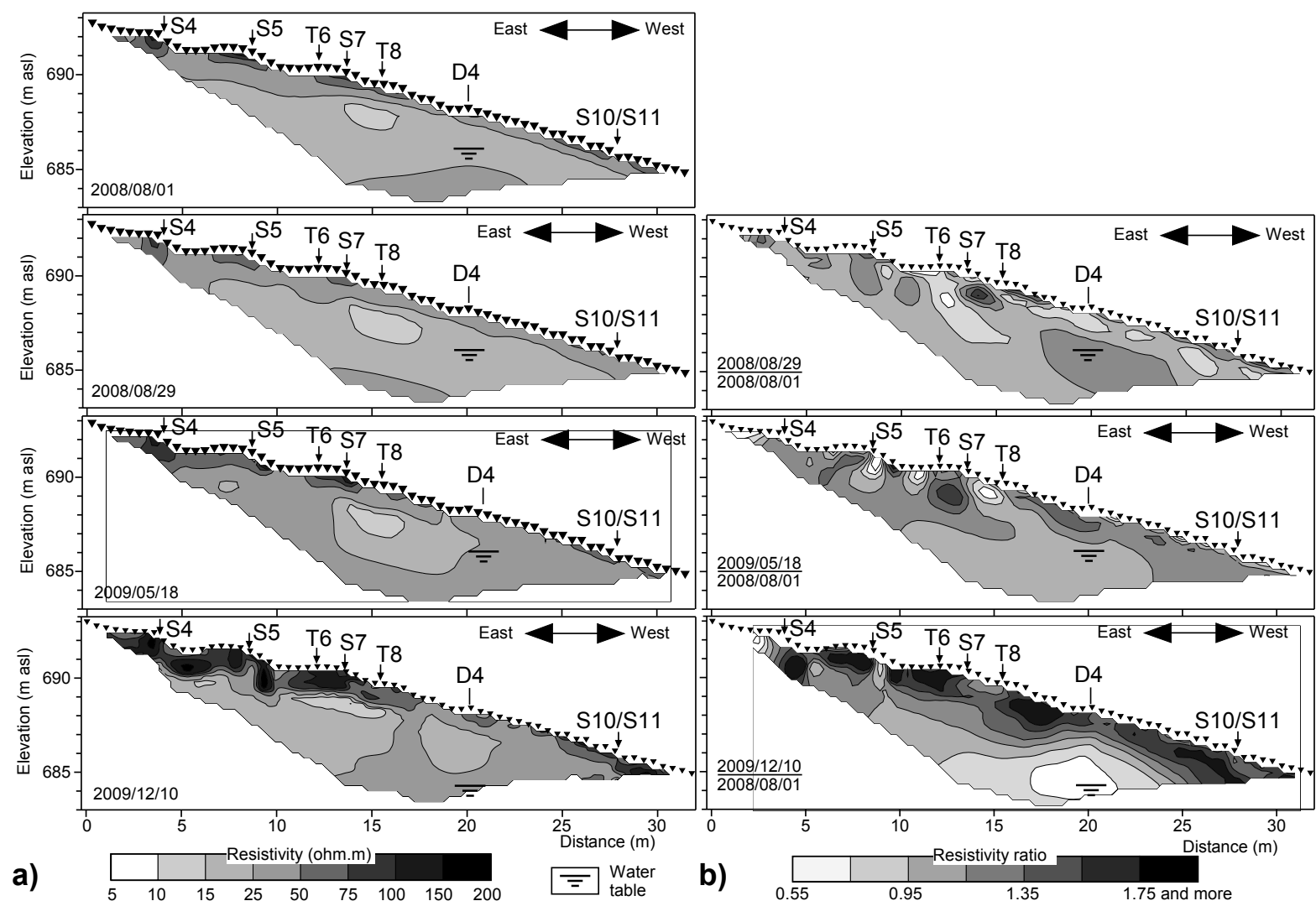

Figure 10: Electrical resistivity monitoring along profile EP2. a) Inverse resistivity sections at four times $(2008 / 08 / 01,2008 / 08 / 29,2009 / 05 / 18$, and 2009/12/10). Absolute errors are $4.8 \%, 4.7 \%, 3.9 \%$ and $4.2 \%$ after 3 iterations, respectively. Resistivity values measured in December 2009 were temperature-corrected. b) Resistivity ratios obtained from the inversion of the data sets of 2008/08/29, 2009/05/18, and 2009/12/10, considering the initial data set of $2008 / 08 / 01$ as a reference. Water table level within borehole D4 is indicated. 

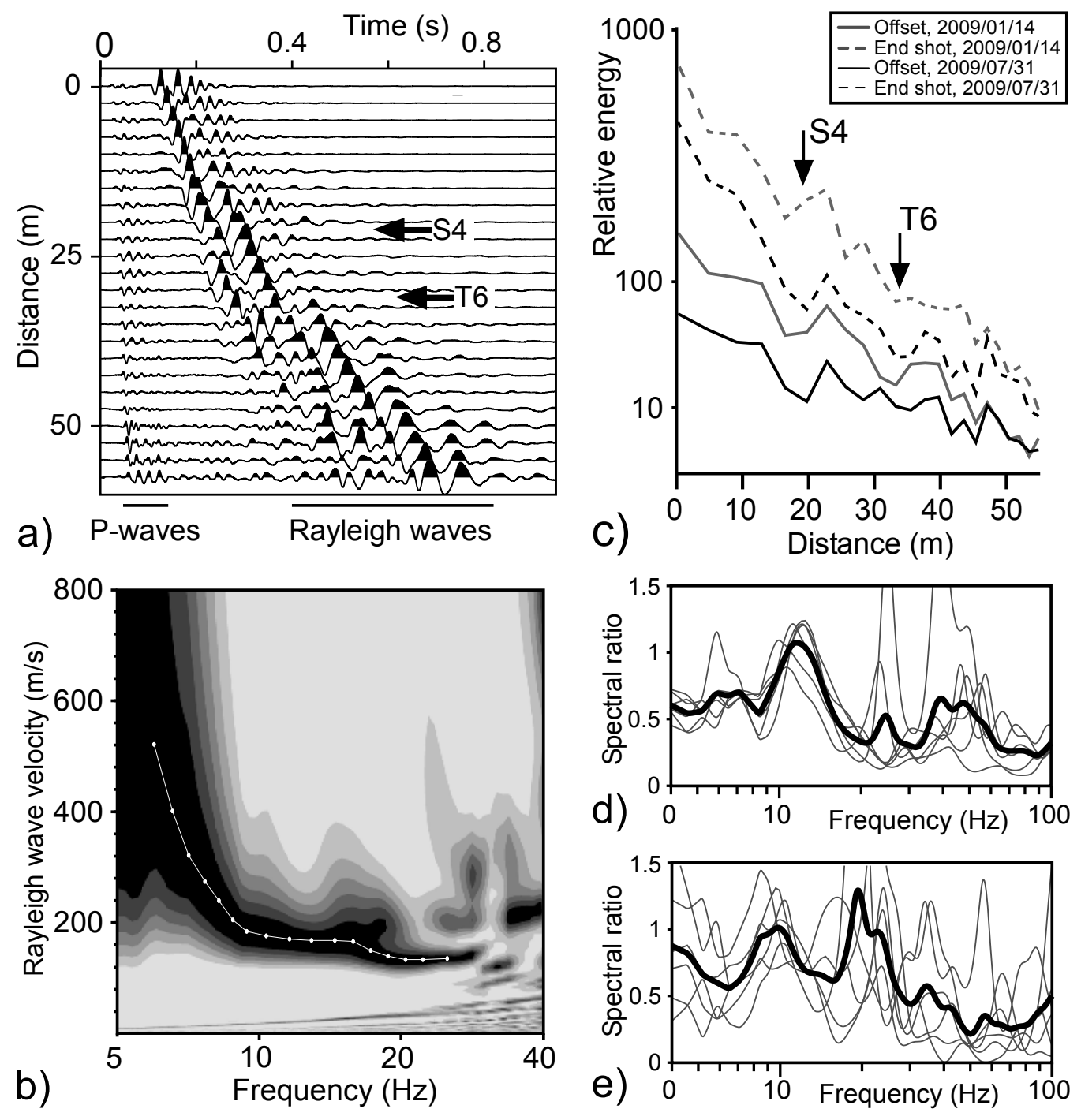

Figure 11: Geophysical characterisation of fractures using Rayleigh surface waves along profile SP (location in Figure 4a). a) Normalized signals with P-waves and Rayleigh waves for an offset shot at $-20 \mathrm{~m}$. S: scarp; T: tension fissure (location of S4 and T6 in 4). b) Experimental dispersion curve for an offset shot and a group of 13 geophones between 15 and $35 \mathrm{~m}$. The white dotted line stands for the trustworthy part of the fundamental mode of the dispersion curve between 6 and $30 \mathrm{~Hz}$. c) Attenuation of Rayleigh waves energy for 2 offset shots and 2 end shots at -20 and $0 \mathrm{~m}$, respectively. S: scarp; T: tension fissure. d) Spectral ratios of transmitted over incident surface waves frequency for a fissure located at a distance of $21 \mathrm{~m}$ along profile SP (S4; location in Figure 4). e) Spectral ratios of transmitted over incident surface waves frequency for a fissure located at a distance of $31 \mathrm{~m}$ along profile SP (T6; location in Figure 4). 


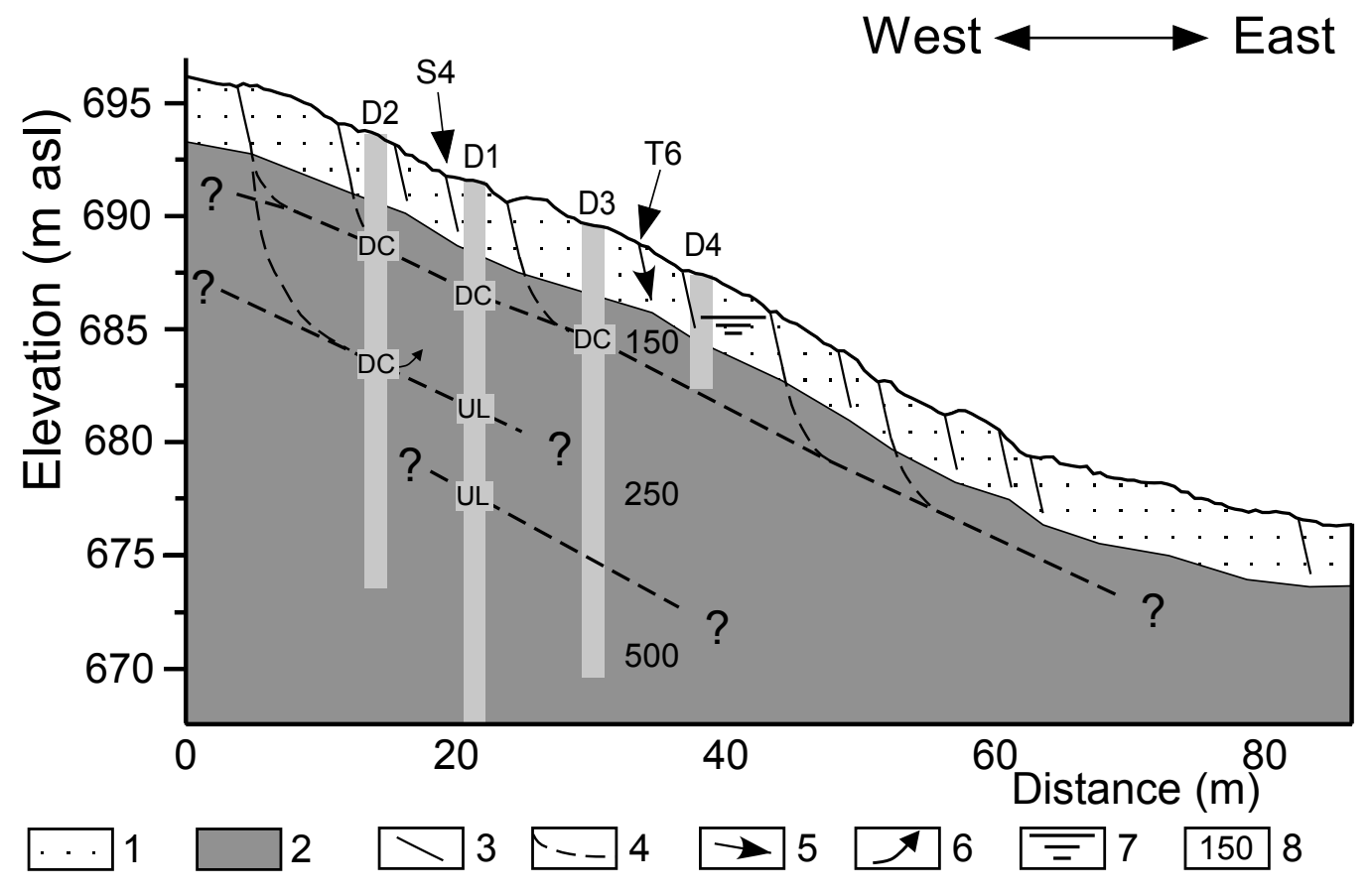

Figure 12: Synthetic model depicting the relationships between fissures, slip surfaces and water infiltration in the Trièves area. 1: Morainic colluvium. 2: Blocky clays. 3: Tension fissures and scarps (S4 and T6 are indicated). 4: Interpreted pattern of slip surfaces. 5: Water infiltration from the surface. 6: Water infiltration in the ground. 7: Water table level. 8: S-wave velocity. DC: deformed casing. UL: Unrecovered level. D1 to D4: Drillings. 